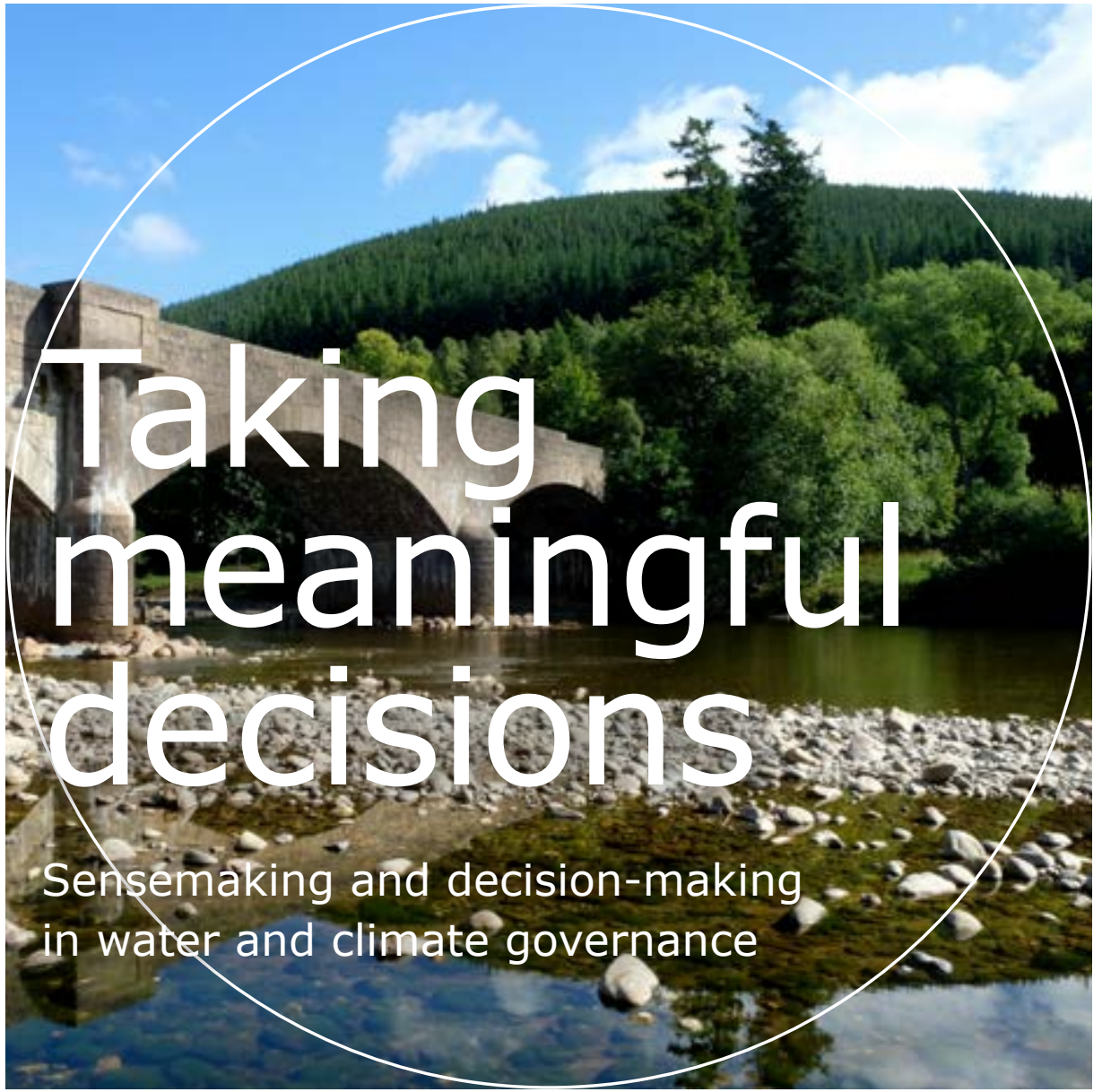

Prof. dr Art R.P.J. Dewulf

Inaugural lecture upon taking up the position of Personal Professor of sensemaking and decision-making in policy processes at Wageningen University \& Research on 7 February 2019 



\section{Taking meaningful decisions Sensemaking and decision-making in water and climate governance}

\section{Prof. dr Art R.P.J. Dewulf}

Inaugural lecture upon taking up the position of Personal Professor of sensemaking and decision-making in policy processes at Wageningen University \& Research on 7 February 2019 
DOI HTTPS://DOI.ORG/10.18174/471091

ISBN 978-94-6343-424-9 


\section{Taking meaningful decisions Sensemaking and decision-making in water and climate governance}

Esteemed rector magnificus, dear colleagues, students, family and friends,

\section{Let me tell you a story}

Back in 2014 we decided to spend our family holiday in Scotland. We took the ferry to Newcastle and we drove up to the nice little town of Ballater, next to the river Dee. We put up our tent on the campsite, from which we had a nice view of the Ballater bridge. We very much enjoyed visiting castles, and walking and biking in the Scottish hills. The weather was great for over a week, until it started to rain, and it kept raining for 24 hours in a row. The next morning, we woke up to the sight of river water entering the campsite. In fact, some people woke up in this water, so we were lucky to be a bit higher up.

We were trying to make sense of what was going on, and we were pondering what we should do. We talked to people, some of whom had been coming to this site for years, and they told us they had seen this before: "sometimes the water gets onto that side of the campsite, but you should be okay over there". That reassured us somewhat, but we kept a close look on the water and started packing our stuff, just in case. As the river was swelling, the water kept rising, slowly but steadily.

The campsite managers were a couple of Australians who, for the first time, were spending their winter, our summer, in Scotland. They were also struggling to make sense of the situation and faced a difficult decision whether to evacuate or not. In the end they decided to evacuate the lower half of the campsite. We were still fine, but other people started moving out. A bit later the fire brigade came onto the site. They came back from a rescue operation upstream, where they had picked up some tourists trapped by the rising water. Their view on the situation was rather different. They had seen how the river was flooding large areas upstream, near the town of Braemar. "This entire campsite could be flooded in two hours time", they told us, and they ordered a full-fledged evacuation. In fact, the water reached our tent in twenty minutes. 
It turned out we were looking in the wrong direction: the water did not come at us from the nearby banks of the river, but from behind. The river had breached the banks around the bend of the river, flooding an entire golf course before submerging the campsite. This caught us by surprise. With the help of our two brave children, Yannis and Elina, we managed to get all our belongings out of the tent and into the car, just in time to get to a safer place in town. We had to leave our tent behind. By that time, the water was knee-high and my boots were filled with water. Fortunately, we were well received in the local town hall, where we found shelter, food and a place to roll out our sleeping bags again. For the final days of our vacation in Scotland, we were hosted by a friendly family, where we watched a lot of television and learned to drink tea with milk.

What we see in this story is that sensemaking and decision-making go along as events unfold, for us as a family, but also for the campsite managers and the fire brigade, in a situation that is full of uncertainty and confusion. People try to develop an understanding of what is going on at the same time as deciding what to do. The answers to these questions are not just informed by rational thinking. They are influenced by whom you are talking to, what you are doing, what you are observing as a result, and by what you are noticing and overlooking.

Sensemaking didn't stop when the water had receded. People who were old enough to remember hadn't seen this kind of flood in 40 years. The newspapers reported that the remnants of hurricane Bertha provoked the unusually heavy rainfall. Could this happen again, we wondered? In fact, it did happen again, in the same town of Ballater one and a half years later, on the last day of the year 2015. This time the remnants of hurricane Frank were to blame. Heavy rainfall came down at a time when the soil was already saturated, and unusually high winter temperatures were causing the snow to melt at the same time. This flood was much more severe. There were no guests at the campsite, but most of the static caravans were displaced, and many of them washed down the river. Houses near the river were severely affected and nearly half of the town was flooded. A considerable stretch of the nearby road was destroyed by the river.

Again, these events and their aftermath were challenging in terms of sensemaking and decision-making. Inhabitants of Ballater couldn't remember a flood like this: it turned out to be the worst flood in 200 years. The municipality had to decide how to go about the repairs. Should everything be restored to its previous state, or was it time to rethink the infrastructure? The Scottish Environmental Protection Agency, who are in charge of flood risk management, had to decide whether they would change their policy. Was this indeed the kind of flood that is to be expected once in 
200 years, or are we witnessing the impacts of a changing climate? They concluded the flood was within the limits of what could be expected, and decided not to change the current policy, except for improving the flood warning system.

Ladies and gentlemen, I am fascinated by how people make sense of difficult water and climate problems, and how that relates to the ways in which decisions are made about these problems. When people are confronted with difficult problems, two basic questions arise. What is going on here? That's the sensemaking question. And, what should we do? That's the decision-making question. Sensemaking is about attaching meaning to what is going on. Is this normal? Has this happened before? Is this a flood? Is this the future? Decision-making is about making choices between different courses of action. Should we warn people or rather avoid panic? Should we evacuate or wait and see what happens? Should we repair the road or construct a new one? Should we change our flood management policy because of climate change, or should we continue with business-as-usual?

\section{Water and climate governance}

Taking meaningful decisions about water and climate issues couldn't be more relevant today. Water is essential for human development across the globe, yet four billion people face severe freshwater scarcity and water demand is expected to increase substantially over the coming decades (Mekonnen \& Hoekstra, 2016; Vörösmarty, Hoekstra, Bunn, Conway, \& Gupta, 2015). Groundwater reserves, accounting for more than half of the irrigation water globally, are dwindling (Carlson, 2017). At the same time more people are affected by flooding: due to urbanization of delta areas, global flood losses are estimated to increase from US $\$ 6$ billion per year in 2005 , to US $\$ 52$ billion per year in 2050. Climate change and soil subsidence could double that figure (Hallegatte, Green, Nicholls, \& Corfee-Morlot, 2013). Both water scarcity and major river floods are projected to increase with the level of warming in the 21st century (IPCC, 2014), resulting in considerable climate change adaptation challenges (Biesbroek et al., 2010; Ludwig, van Slobbe, \& Cofino, 2013).

According to the OECD (2011), the water crisis is mainly a governance crisis. Several solutions have been proposed, including better monitoring, inclusive decisionmaking processes and strengthening governance capacity at multiple scales (Garrick et al., 2017). At the same time, water and climate governance remain contested, with on-going debates about the evidence base, public-private responsibilities, the role of the market and the scales at which to address these issues (Woodhouse \& Muller, 2017). Because of their intractable, cross-cutting, and contested nature, many water 
and climate governance issues can be understood as wicked problems (Freeman, 2000; Levin, Cashore, Bernstein, \& Auld, 2012). Wicked problems (Churchmen, 1967; Head, 2015; Rittel \& Webber, 1973; Roberts, 2000; Termeer, Dewulf, Breeman, \& Stiller, 2015; Xiang, 2013) are "social system problems which are ill-formulated, where the information is confusing, where there are many clients and decision makers with conflicting values, and where the ramifications in the whole system are thoroughly confusing" (Churchmen, 1967, p. B-141).

Take the example of Lima, the second largest city in the world that is located in a desert. You have 10 million people here, in a growing city, but it never rains. Water scarcity is always a concern here. Lima's water supply depends primarily on the rainfall and the rivers coming down from the Andes mountains. But climate change is affecting these rainfall patterns, the highlands are degrading, and water is increasingly polluted. The problem looks unsolvable from the start, but still decisions have to be made. So why are these decisions so difficult? First of all, the web of interdependencies between the actors is very complex. Second, crucial information is either lacking or highly uncertain. And third, there is high ambiguity: people disagree about what exactly the problem is.

\section{Sensemaking and decision-making}

Is life about choice or is life about meaning? This intriguing question was posed by James G. March (1991), one the founding fathers of decision-making theory. Indeed, sensemaking and decision-making represent rather different perspectives on different types of human activities. Decision-making is very much concerned with the future and the possibilities it holds, and aims to overcome uncertainty to make choices possible. In contrast, sensemaking is primarily about attaching meaning to actions and events that have already occurred. A sensemaking perspective (Weick, 1995; Weick, Sutcliffe, \& Obstfeld, 2005) emphasizes the continuous flow of action and interaction, in which people struggle to overcome ambiguity about the significance of their own and others' experiences and actions. So, sensemaking and decision-making theories don't seem to fit together very well. Still, the argument I want to make is that our understanding of water and climate governance can be advanced by exploring the links between decision-making and sensemaking theories. What do I mean with governance, and how does it relate to decision-making and sensemaking? Governance involves attempts by public or private actors to provide collective organization and action, thereby steering society in one direction rather than another (Peters \& Pierre, 2016). Decision-making is one of the key processes in governance, if not the essence of it (Peters \& Pierre, 2016). Public and/or private actors take numerous individual and collective decisions in their attempts to address 
issues of public concern. The governance of wicked problems is characterized by thorny choice dilemmas, confusion about who is supposed to take decisions, and conflict about which rules or decision criteria to apply. Because many actors are involved, sensemaking is another key process in governance, apparent in the conflicting frames that actors use to make sense of the issues. Sensemaking thrives when uncertainty and ambiguity are high. If there is little certainty and much confusion, sensemaking shifts into a higher gear. Wicked problems abound with uncertainty and ambiguity: the nature of the problem is itself in question, the reliability of information is problematic, interpretations are conflicting, and causeeffect relationships are opaque (Weick, 1995).

In sensemaking theory, the emphasis is on how people make sense of complex situations

through acting in those situations and constructing what the meaning of the situation might be, usually through interacting with others. Sensemaking operates through the processes of enactment, selection and retention (Weick, 1979, 1995; Weick et al., 2005). People are engaged in ongoing projects and take actions in a confusing world, and those enactments produce ambiguous situations and experiences of which certain portions are singled out for interpretation. In making sense of these bracketed portions of experience retrospectively, certain interpretations are selected over others. When these lead to satisfactory results, they may be retained as meanings available for the next sensemaking occasion.

Both sensemaking and decision-making are of prime importance for governing wicked water and climate problems. Furthermore, they are interrelated. Decisionmaking strongly relies on sensemaking, and at the same time, sensemaking strongly relies on decision-making. In conditions of high uncertainty and ambiguity, sensemaking is decisive in many ways. The enactment and bracketing of experience, the way problems get framed, the assumed degree of certainty and uncertainty, the interactive cycles of reducing ambiguity all drive what will and will not be considered as a situation requiring a decision, and which decision options will be considered logical, effective, appropriate or meaningful. Equally important, the process of decision-making produces a sense of what is going on. Decision-making moments are prime occasions for sensemaking, and in a more fundamental way making a decision is a form of enactment, the initial step in the sensemaking model.

Governance is studied by many public administration and policy scholars (Rhodes, 2007; Stoker, 1998; Torfing, Peters, Pierre, \& Sorensen, 2012), where it is often approached from an institutional perspective, focusing on organizational structures, the allocation of public and private responsibilities, or accountability procedures. The 
core question for my research concerns the relation between the interactional processes of sensemaking and decision-making in water and climate governance. It is about how governance actors interact with their environment and with each other. It is about how decisions are shaped by what makes sense and what doesn't make sense to decision makers. It is about how they discover through their decisions what the meaning is of the problem they are dealing with. To understand this relation better, we need to discuss different logics of decision-making.

\section{The decision-making logic of meaningfulness}

How do people make decisions? Scholars in a variety of disciplines have studied individual, organizational and governmental decision-making for decades. Public administration and policy researchers often distinguish between two dominant logics of decision-making (March, 1994; March \& Olsen, 1989; Peters \& Zittoun, 2016; Schmidt, 2008). First, the logic of consequentiality, according to which decisions are made based on the expected consequences of decision options in terms of a given set of preferences. Second, the logic of appropriateness, according to which decisions are guided by institutionalized rules that prescribe what needs to be done by particular people in particular situations. I build on the sensemaking approach to develop a third logic of decision-making: the logic of meaningfulness, according to which decisions are guided by how the decision-makers make sense of the decision problems.

The decision-making logic of consequentiality originates in theories of rational choice (Simon, 1955), which assume that alternative decision options are assessed in terms of their expected consequences (March, 1994). Key questions here are: What are the decision options? What are my preferences? What are the consequences of the different options for my preferences? Which option has the most favourable consequences?

For example, deciding about water conservation measures in the Peruvian highlands can be guided by a cost-benefit analysis of the expected consequences for upstream and downstream stakeholders. The assumptions of rational choice theories have often been challenged by empirical studies of real-world decision making (Jones, 2002; March, 1978). Often, not all alternatives are known and there is uncertainty about their consequences. Furthermore, decision makers do not have the time to consider all the possible consequences, they have incomplete and inconsistent goals, so they satisfy rather than maximize (Jones, 1999; March, 1994). This led to alternative theories of bounded rationality, portraying decision-makers as operating under more or less severe constraints, but still intending to make rational decisions guided by the expected consequences of different options. 
The decision-making logic of appropriateness regards decisions not so much as intendedly rational choices but as rule-based actions (March, 1994; March \& Olsen, 1989). Key questions here are: Which role do I have in this situation? What is expected of me, given my role in the situation? Which rules apply to this decision? Which decision options are most appropriate? For example, deciding about water conservation measures in the Peruvian highlands can be guided by the new national rule that water utilities have to invest in benefit-sharing mechanisms with highland communities. Standard operation procedures, professional standards, cultural norms and regulations guide the choices of decision-makers(March, 1991). Decision-making in the logic of appropriateness revolves around rules, obligations and what others expect from decision-makers in particular situations.

According to the logic of meaningfulness, decisions are guided by how the decisionmakers make sense of decision problems. Key questions here are: What is going on? Who can I interact with to discover what the situation means? Which interpretation of the situation makes most sense? Which decision options are most meaningful? For example, deciding about water conservation measures in the Peruvian highlands can be guided by the meaning of highlands as sources of water for cities downstream, their meaning as living space of local communities, or their meaning as hotspots of biodiversity.

The logics of consequentiality and appropriateness provide less and less guidance as clarity about the consequences and the appropriateness of decision options deteriorates. Therefore, the logic of meaningfulness becomes particularly relevant where decision-making faces high degrees of uncertainty and ambiguity (Dewulf, Craps, Bouwen, Taillieu, \& Pahl-Wostl, 2005; M. S. Feldman, 1989; March, 1996; Stone, 2002; Zahariadis, 2003). Here, decisions become strongly driven by how the decision-makers makes sense of the situation in terms of what the decision is really about, what it means, and what the relevant options are.

The logic of meaningfulness builds on March's work on decision-making and ambiguity (March, 1978, 1994), but goes a step further by drawing on sensemaking theory (Weick, 1995). While bearing some resemblance to discursive institutionalism (Schmidt, 2008), the logic of meaningfulness is rather distinct in its focus on decisionmaking, and its emphasis on interactions rather than institutions. The logic of meaningfulness emphasizes the central role of ambiguity, understood as "the simultaneous presence of multiple valid, and sometimes conflicting, ways of framing a problem" (Brugnach, Dewulf, Pahl-Wostl, \& Taillieu, 2008; M. S. Feldman, 1989). Interpretive policy analysts interested in decision-making have also stressed that ambiguity is not only a nuisance for decision-makers - vague and ambiguous goals 
can unite different groups who otherwise would disagree on specifics (Stone, 2002). At the same time defining decision problems, listing alternative options and evaluating them is highly amenable to interactional framing (Dewulf et al., 2009). Decision-making in collaborative settings depends on connecting frames (Dewulf, Mancero, Cardenas, \& Sucozhanay, 2011; Gray \& Purdy, 2018), while in competitive settings decision-makers strategically manipulate ambiguity by employing labels and symbols that affect meaning, highlighting one dimension of the problem over others (Zahariadis, 2003). Providing meaning and clarity in a world replete with ambiguity and problematic preferences is a powerful political tool. Decision-making, then, is often more like a struggle over meaningfulness than like an orderly process of assessing consequences or following rules.

The logic of meaningfulness can theoretically be positioned at the cross-roads between decision-making theory (where interpretation and meaning are rarely the central focus of attention) and interpretive policy analysis (Fischer \& Forester, 1993; Hajer \& Wagenaar, 2003; Schmidt, 2008; Yanow, 1993) (where the activity of decisionmaking is rarely the primary phenomenon of interest). Decision-making is getting renewed attention in the policy and governance literature (Cairney \& Weible, 2017; Peters \& Pierre, 2016). Furthermore, there are calls to improve on dominant decisionmaking theories because "they are not concerned with how decision makers make sense of or interpret a given decision problem" (Tuckett et al., 2015). Further developing the logic of meaningfulness has the potential to make an important contribution here.

Within this overall research vision, I have established three research lines that I want to develop further: uncertainty, ambiguity and decision support. These research lines contribute to adaptive, collaborative and informational governance theories respectively. I will try to give you a flavour of each of them.

\section{Uncertainty}

The first research line is uncertainty and focuses on sensemaking and decisionmaking when information is lacking. Here I study how actors make sense in and of uncertain decision-making situations, and how robust and/or flexible decisionmaking contributes to adaptive governance.

What climate change does to water governance is introducing fundamental uncertainty about future water conditions (Dewulf \& Biesbroek, 2018; Jensen \& Wu, 2016).

Think about the challenges for the water utility of Lima. They need to decide on water infrastructure to ensure the future water supply for the city. One question here 
is how do they make sense of the future? Do they understand the future as largely predictable or do they understand it as a range of possible scenarios?

The way in which we make sense of what we know and what we don't know guides our decision-making. It tells us when to reconsider business-as-usual, or what range of scenarios to prepare for. If they are to have any chance of being effective, water and climate governance processes need to be adaptive, for example by taking robust decisions that are effective under a range of different scenarios (Lempert, Groves, Popper, \& Bankes, 2006), or taking flexible decisions that can be continuously adjusted when circumstances change (Pahl-Wostl et al., 2007), or when unexpected events occur (Sutcliffe \& Weick, 2007). In terms of sensemaking, noticing small failures, resisting oversimplification and imagining worst case scenarios are crucial elements (Sutcliffe \& Weick, 2007). Recent advances in policy analytic tools for scenario exploration and adaptation pathways (Haasnoot et al., 2014; Kwakkel, Walker, \& Haasnoot, 2016) and the application of adaptive delta management in the Delta Programme (Dewulf \& Termeer, 2015) attest to the relevance of this research line, and to the need for studying these approaches in a broader adaptive governance context (Folke, Hahn, Olsson, \& Norberg, 2005; Karpouzoglou, Dewulf, \& Clark, 2016).

\section{Ambiguity}

This second research line is ambiguity, and focuses on sensemaking and decisionmaking when frames conflict. Here I study how actors make sense in and of ambiguous decision situations, and how frame connection contributes to collaborative governance.

For example, how to make sense of the water scarcity problem in a booming city like Lima? Do we frame this as a water supply problem, because not enough water is flowing from the Andes highlands to the city? If we do so, it makes sense to decide on measures for harvesting more water from those highlands, or even transfer it from the other side of the Andes by drilling tunnels through the mountain. Or do we frame it as a water demand problem, because water in Lima is used in very inefficient ways, for example to water green lawns in what is basically a desert? In that case, it makes more sense to decide on measures for saving water or using it more efficiently. Or still different, is it a problem of urban planning, leaving entire sectors of the city without basic services, or rather a problem of water injustice in terms of unfair distribution of the available water? Governance actors disagree about how to frame this problem, and still they depend on each other to take decisions in collaborative governance arrangements. 
Processes of sense-making are often triggered by the experience of ambiguity, i.e. when the situation looks odd or puzzling and the issue can potentially be framed in different ways (Brugnach, Dewulf, Henriksen, \& Van der Keur, 2011; Zahariadis, 2003). Wicked problems in water and climate governance provide endless possibilities to be framed differently by different actors, according to different ways of knowing (Ingram \& Lejano, 2009). These frame conflicts pose big challenges for governance processes: how can decisions be taken that effectively address the problem if we don't agree about what the problem is in the first place? If they are to have any chance to be effective, water and climate governance processes need to steer away from frame polarization and achieve some form of frame connection (Dewulf \& Bouwen, 2012; Rist, Chiddambaranathan, Escobar, \& Wiesmann, 2006). Whether governance actors can achieve meaningful common ground through collectively making sense of the complex problem domain is a key factor for successful collaborative governance (Ansell \& Gash, 2007; Dewulf et al., 2011; Gray \& Purdy, 2018; Vangen, Hayes, \& Cornforth, 2015).

\section{Decision support}

My third research line builds on the previous two and is about ways to support sensemaking and decision-making in the digital age. Here I study how knowledge and information are used in decision-making processes, and what the role is of digital decision-support systems in informational governance.

Developments in ICT, social media, and mobile internet have dramatically increased our possibilities to collect, combine, and share information. Digital sources of information have become part of parcel of decision-making practices. This has expanded the possibilities for designing powerful decision-support systems, also for less standardized and more complex decision tasks (Burstein \& Holsapple, 2008). These systems usually target a specific decision-making task, and are based on an analysis of what the relevant parameters and decision options are for a specific decision maker. Whether digital decision-support systems are actionable (Dewulf, Craps, Bouwen, Abril, \& Zhingri, 2005; Kirchhoff, Carmen Lemos, \& Dessai, 2013) depends on whether the provided information makes sense to decision-makers. This challenge is particularly relevant for water and climate issues, given their knowledgeintensive nature (D. L. Feldman \& Ingram, 2009; Leeuwis \& Aarts, 2011; Lemos, Kirchhoff, \& Ramprasad, 2012).

There is also potential to support decision-making by targeting sensemaking processes more directly through sensemaking-support systems (Muhren \& Van De Walle, 2010). In crisis situations, for example, establishing a sense of what is going on 
in confusing circumstances requires entertaining different interpretations as potentially valid ones, even under time pressure (Sutcliffe \& Weick, 2007). But also in long term decision-making, it is important to go beyond the currently relevant decision parameters to support decision-making. Supporting sensemaking through monitoring upcoming challenges, weak signals or unexpected developments might uncover decision parameters for the future, which is crucial for supporting decisionmaking in the long term.

Designing decision-support and sensemaking-support systems in the digital age requires in-depth analysis of decision-making processes and a broad understanding of informational governance (Mol, 2006) with all the opportunities and pitfalls attached to it.

\section{Taking meaningfull decisions}

How can I know what I think, until I see what I say? (Weick, 1979). With this phrase, Weick captured the retrospective nature of sensemaking. What we like to think of as good reasons for decisions are often rationalizations and justifications of those decisions, established after the fact.

The relation between sensemaking and decision-making can perhaps be captured by variations on Weick's phrase. Put yourself in the shoes of a policy maker confronting a difficult issue. First, how can I know what we decide, until I see what it means? Which decision turns out to be the important one, or what turns out to be important about a decision, can often only be recognized in hindsight. Second, how can I know what we mean, until I see what we decide? What is really significant, what defines an organization's purpose, may only become clear through an important decision.

The challenge here is one of taking meaningful decisions: choices for concrete actions that provide a meaningful perspective. Uncertainty and ambiguity turn decisionmaking in water and climate governance into a potential minefield. The risk is that policy makers retreat into symbolic policy - big words without concrete choices - or into bureaucratic or technocratic fixes that may increase efficiency but do not provide a meaningful perspective.

Taking meaningful decisions is about actions, not just endless deliberation. It is about the creation of meaning, not just discrete choices. Meaningful decisions are about significance, not just spin. Meaningful decisions are not single grand acts, they require continuous attention and elaboration, because their meaning develops over time. What was meaningful for the decision-makers at one point in time may no longer be meaningful when it lands on the table of the implementers, or when it 
starts affecting people's lives. What seemed like an insignificant choice at one point in time may turn out to be a very meaningful decision further down the road.

Keeping options open and noticing weak signals is as important to meaningful decision-making as entertaining multiple interpretations and noticing entirely different frames. Most importantly, meaningful decisions are interactional accomplishments, not unilateral impositions. This does not mean everybody has to agree, or that the problem will be solved once and for all. Taking meaningful decisions in water and climate governance requires the courage to address wicked problems without expecting final solutions, and the commitment to search for a meaningful perspective, without expecting to find the ultimate one.

\section{Acknowledgements}

Even though I'm the one who gets to deliver an inaugural lecture here today, this is far from an individual achievement. A great number of people have supported and inspired me during my years at this university and they deserve my deepest gratitude.

I want to thank Wageningen University, our rector Arthur Mol, our director Jack van der Vorst, the Academic Board and the members of the appointment committee, for entrusting me with this position.

In 2007, Katrien Termeer took the risk of hiring me as an Assistant Professor at the Public Administration and Policy Group. I want to thank Katrien, not only for being a great boss and a fine colleague, but also for her strong support throughout the exciting but sometimes stressful trajectory of the tenure track.

The people who have probably contributed most significantly to my research are the $\mathrm{PhD}$ candidates and postdocs, so they deserve a special word of thanks. I had, and still have, the pleasure to work with them on exciting topics: with Nicola Isendahl on the framing of uncertainties (Isendahl et al., 2009), with Geeske Scholz on agentbased modelling of social learning (Scholz, Dewulf, \& Pahl-Wostl, 2014), with Maartje van Lieshout on scale framing (Van Lieshout, Dewulf, Aarts, \& Termeer, 2017), with Martijn Vink on the framing and governance of adaptation in the Dutch Delta (Vink, Boezeman, Dewulf, \& Termeer, 2013), with Sam Grainger on scale framing and visualizations in Peruvian water management, with Tim Stevens on framing processes in social media (Stevens, Aarts, Termeer, \& Dewulf, 2016), with Timos Karpouzoglou on adaptive water governance in mountain areas (Karpouzoglou et al., 2016), with Javier Gonzalez on multi-level learning in climate change adaptation in Bolivia, with Andy Nyamekye and Rebecca Sarku on environmental virtual 
observatories and adaptive decision-making in Ghana (Nyamekye, Dewulf, Van Slobbe, Termeer, \& Pinto, 2018), with Wieke Pot on forward-looking decisions on water infrastructure (Pot, Dewulf, Biesbroek, \& Verweij, 2019), with Katarzyna Cieslik on flood resilience and development in Nepal (Cieslik et al., 2018), with Daniel Wiegant on landscape restoration in Ecuador, and with Christel van Eck on the role of bloggers in the public debate about climate change.

I want to thank my colleagues at the Public Administration and Policy group, Otto, Sylvia, Robbert, Jeroen and Tamara, and the many PhDs and postdocs, for making our chair group such an exciting place to work. Special thanks go to our secretary Maarit Junnikkala for making my working life so much easier.

What makes Wageningen my favourite university is its commitment to interdisciplinarity. I've had the pleasure to work with inspiring people at other social science groups, like Noelle Aarts, Cees Leeuwis, Esther Turnhout, Simon Bush, Bas Arts, Jeroen Warner, Paul Opdam and many more. I particularly enjoy teaching and researching together with the water and climate experts at the Water Systems and Global Change group, the Water Resource Management group, and Wageningen Environmental Research, including Carolien Kroeze, Erik van Slobbe, Fulco Ludwig, Saskia Werners, Petra Hellegers, Jeroen Vos Pieter van Oel and Annemarie Groot.

Scientific research is not served by containing oneself in one university or one country. I have had the pleasure to work on issues of water and climate governance with people like Dave Huitema, Sander Meijerink and Arwin van Buuren in the Netherlands, Marcela Brugnach, Claudia Pahl-Wostl and Jens Newig in Germany, Wouter Buytaert, Julian Clark, David Hannah, and Mike Hulme in the UK, and Maria Carmen Lemos and Richard Moss in the US. Beyond the boundaries of the academic world, I want to thank Maarten van der Vlist at Rijkswaterstaat, Lilian van den Aarsen at the Ministry of Infrastructure and Water Management, Hetty Klavers and Bert Rietman at Waterschap Zuiderzeeland, and Hans Mommaas and Willem Ligtvoet at the Dutch Environmental Assessment Agency, for their cooperation in research projects.

A special word of thanks goes to Barbara Gray, emeritus professor at Penn State University, whose work is invaluable to me, and who has been my mentor-at-adistance throughout my academic career.

Over the past 10 years I have been part of Cycloop - the network for action research and facilitation of multi-actor collaboration. I want to thank Koen, Marc and Johan for this. This network also kept me in contact with René Bouwen and Tharsi Taillieu, from whom I learned most of what I know about organizations. 
Finally I want to thank the people who are closest to me: my family and in-laws, my parents, who have always supported my choices in life, my children Yannis and Elina, who always remind me of what is really important in life, and who gave me permission to use our adventures in Scotland for this lecture, and of course Petra, who had the courage to move with me and start a new life in Wageningen, and whose love and wisdom inspire me every day.

Ladies and gentlemen, thank you all for being here.

Ik heb gezegd. 


\section{References}

- Ansell, C., \& Gash, A. (2007). Collaborative Governance in Theory and Practice. Journal of Public Administration Research and Theory, 18(4), 543-571. https://doi.org/10.1093/jopart/ mum032

- Biesbroek, G. R., Swart, R. J., Carter, T. R., Cowan, C., Henrichs, T., Mela, H., ... Rey, D. (2010). Europe adapts to climate change: Comparing National Adaptation Strategies. Global Environmental Change, 20(3), 440-450. https://doi.org/10.1016/j.gloenvcha.2010.03.005

- Brugnach, M., Dewulf, A., Henriksen, H. J., \& Van der Keur, P. (2011). More is not always better: coping with ambiguity in natural resources management. Journal of Environmental Management, 92(1), 78-84. https://doi.org/10.1016/j.jenvman.2010.08.029

- Brugnach, M., Dewulf, A., Pahl-Wostl, C., \& Taillieu, T. (2008). Toward a relational concept of uncertainty: about knowing too little, knowing too differently, and accepting not to know. Ecology and Society, 13(2), 30.

- Burstein, F., \& Holsapple, C. (2008). Handbook on Decision Support Systems 1: Basic Themes. Heidelberg: Springer eBooks. https://doi.org/10.1007/978-3-540-48713-5

- Cairney, P., \& Weible, C. M. (2017). The new policy sciences: combining the cognitive science of choice, multiple theories of context, and basic and applied analysis. Policy Sciences, 50(4), 1-9. https://doi.org/10.1007/s11077-017-9304-2

- Carlson, C. (2017). The emptying well. Nature, 542, 412-413.

- Churchmen, C. W. (1967). Wicked Problems. Management Science, 13(4), B-141-142. https:// doi.org/10.1287/mnsc.14.4.B141

- Cieslik, K. J., Leeuwis, C., Dewulf, A. R. P. J., Lie, R., Werners, S. E., van Wessel, M., ... Struik, P. C. (2018). Addressing socio-ecological development challenges in the digital age: Exploring the potential of Environmental Virtual Observatories for Connective Action (EVOCA). NJAS - Wageningen Journal of Life Sciences, 86-87(July), 2-11. https://doi.org/10.1016/j. njas.2018.07.006

- Dewulf, A., \& Biesbroek, R. (2018). Nine lives of uncertainty in decision-making: strategies for dealing with uncertainty in environmental governance. Policy and Society, 37(4), 441-458. https://doi.org/10.1080/14494035.2018.1504484

- Dewulf, A., \& Bouwen, R. (2012). Issue Framing in Conversations for Change: Discursive Interaction Strategies for "Doing Differences." The Journal of Applied Behavioral Science, 48(2), 168-193. https://doi.org/10.1177/0021886312438858

- Dewulf, A., Craps, M., Bouwen, R., Abril, F., \& Zhingri, M. (2005). How indigenous farmers and university engineers create actionable knowledge for sustainable irrigation. Action Research, 3(2), 175-192. https://doi.org/10.1177/1476750305052141

- Dewulf, A., Craps, M., Bouwen, R., Taillieu, T., \& Pahl-Wostl, C. (2005). Integrated management of natural resources: dealing with ambiguous issues, multiple actors and diverging frames. Water Science and Technology, 52(6), 115-124.

- Dewulf, A., Gray, B., Putnam, L., Lewicki, R. J., Aarts, N., Bouwen, R., \& van Woerkum, C. (2009). Disentangling approaches to framing in conflict and negotiation research: A meta- 
paradigmatic perspective. Human Relations, 62(2), 155-193. https://doi. org/10.1177/0018726708100356

- Dewulf, A., Mancero, M., Cardenas, G., \& Sucozhanay, D. (2011). Fragmentation and connection of frames in collaborative water governance: a case study of river catchment management in Southern Ecuador. International Review of Administrative Sciences, 77(1), 50-75. https://doi.org/10.1177/0020852310390108

- Dewulf, A., \& Termeer, C. J. A. M. (2015). Governing the future? The potential of adaptive delta management to contribute to governance capabilities for dealing with the wicked problem of climate change adaptation. Journal of Water and Climate Change, 6(4), 759-771. https://doi.org/10.2166/wcc.2015.117

- Feldman, D. L., \& Ingram, H. M. (2009). Making Science Useful to Decision Makers: Climate Forecasts, Water Management, and Knowledge Networks. Weather, Climate, and Society, 1(1), 9-21. https://doi.org/10.1175/2009WCAS1007.1

- Feldman, M. S. (1989). Order without design: information production and policy making. Stanford: University Press.

- Fischer, F., \& Forester, J. (1993). The Argumentative Turn in Policy Analysis and Planning. New York: Springer. https://doi.org/10.1007/s13398-014-0173-7.2

- Folke, C., Hahn, T., Olsson, P., \& Norberg, J. (2005). Adaptive Governance of Social-Ecological Systems. Annual Review of Environment and Resources, 30(1), 441-473. https://doi. org/10.1146/annurev.energy.30.050504.144511

- Freeman, D. M. (2000). Wicked water problems: sociology and local water organizations in addressing water resources policy. Journal of the American Water Resources Association, 36(3), 483-491. https://doi.org/10.1111/j.1752-1688.2000.tb04280.x

- Garrick, D. E., Hall, J. W., Dobson, A., Damania, R., Grafton, R. Q., Hope, R., .. Money, A. (2017). Valuing water for sustainable development. Science, 358(6366), 1003-1005. https://doi. org/10.1126/science.aao4942

- Gray, B., \& Purdy, J. M. (2018). Collaborating for Our Future. Multi-stakeholder Partnerships for Solving Complex Problems. Oxford: University Press.

- Haasnoot, M., Kwakkel, J. H., Walker, W. E., ter Maat, J., Haasnoot, M., \& Walker, W. E. (2014). Developing dynamic adaptive policy pathways: a computer-assisted approach for developing adaptive strategies for a deeply uncertain world. Climatic Change, 23(2), 485-498. https://doi.org/10.1007/s10584-014-1210-4

- Hajer, M. A., \& Wagenaar, H. (2003). Deliberative Policy Analysis. Understanding Governance in the Network Society. Cambridge: University Press.

- Hallegatte, S., Green, C., Nicholls, R. J., \& Corfee-Morlot, J. (2013). Future flood losses in major coastal cities. Nature Climate Change, 3(9), 802-806. https://doi.org/10.1038/nclimate1979

- Head, B. W. (2015). Wicked Problems: Implications for Public Policy and Management. Administration \& Society, 47(6), 711-739.

- Ingram, H. M., \& Lejano, R. P. (2009). Transitions: transcending multiple ways of knowing water resources in the United States. In D. Huitema \& S. Meijerink (Eds.), Water policy 
entrepreneurs: A Research Companion to the Water Transitions around the Globe. Cheltenham, UK: Edward Elgar.

- IPCC. (2014). AR5 Summary for Policymakers. Climate Change 2014: Synthesis Report. Contribution of Working Groups I, II and III to the Fifth Assessment Report of the Intergovernmental Panel on Climate Change. https://doi.org/10.1017/CBO9781107415324

- Isendahl, N., Dewulf, A., Brugnach, M., François, G., Möllenkamp, S., \& Pahl-Wostl, C. (2009). Assessing Framing of Uncertainties in Water Management Practice. Water Resources Management, 23(15), 3191-3205. https://doi.org/10.1007/s11269-009-9429-y

- Jensen, O., \& Wu, X. (2016). Embracing Uncertainty in Policy-Making: The Case of the Water Sector. Policy and Society, 35(2), 115-123. https://doi.org/10.1016/j.polsoc.2016.07.002

- Jones, B. D. (1999). Bounded Rationality. Annual Review of Political Science, 2(1), 297-321. https://doi.org/10.1146/annurev.polisci.2.1.297

- Jones, B. D. (2002). Bounded rationality and public policy: Herbert A. Simon and the decision foundation of collective choice. Policy Sciences, 35(3), 269. https://doi. org/10.1023/A:1021341309418

- Karpouzoglou, T., Dewulf, A., \& Clark, J. (2016). Advancing adaptive governance of social-ecological systems through theoretical multiplicity. Environmental Science \& Policy, 57, 1-9. https://doi.org/10.1016/j.envsci.2015.11.011

- Kirchhoff, C. J., Carmen Lemos, M., \& Dessai, S. (2013). Actionable Knowledge for Environmental Decision Making: Broadening the Usability of Climate Science. Annual Review of Environment and Resources, 38(1), 393-414. https://doi.org/10.1146/annurevenviron-022112-112828

- Kwakkel, J. H., Walker, W. E., \& Haasnoot, M. (2016). Coping with the Wickedness of Public Policy Problems: Approaches for Decision Making under Deep Uncertainty. Journal of Water Resources Planning and Management, 142(3), 01816001. https://doi.org/10.1061/(ASCE) WR.1943-5452.0000626

- Leeuwis, C., \& Aarts, N. (2011). Rethinking communication in innovation processes: Creating space for change in complex systems. Journal of Agricultural Education and Extension, 17(1), 21-36. https://doi.org/10.1080/1389224X.2011.536344

- Lemos, M. C., Kirchhoff, C. J., \& Ramprasad, V. (2012). Narrowing the climate information usability gap. Nature Climate Change, 2(11), 789-794. https://doi.org/10.1038/nclimate1614

- Lempert, R. J., Groves, D. G., Popper, S. W., \& Bankes, S. C. (2006). A General, Analytic Method for Generating Robust Strategies and Narrative Scenarios. Management Science, 52(4), 514-528. https://doi.org/10.1287/mnsc.1050.0472

- Levin, K., Cashore, B., Bernstein, S., \& Auld, G. (2012). Overcoming the tragedy of super wicked problems: constraining our future selves to ameliorate global climate change. Policy Sciences, 45(2), 123-152. https://doi.org/10.1007/s11077-012-9151-0

- Ludwig, F., van Slobbe, E., \& Cofino, W. (2013). Climate change adaptation and Integrated Water Resource Management in the water sector. Journal of Hydrology. https://doi. org/10.1016/j.jhydrol.2013.08.010 
- March, J. G. (1978). Bounded rationality, ambiguity, and the engineering of choice. The Bell Journal of Economics, 9(2), 587-608. https://doi.org/Article

- March, J. G. (1991). How decisions happen in organizations. Human-Computer Interaction, 6(2), 95-117. https://doi.org/10.1207/s15327051hci0602_1

- March, J. G. (1994). A primer on decision making. How decisions happen. New York: The Free Press.

- March, J. G. (1996). Continuity and Change in Theories of Organizational Action. Administrative Science Quarterly, 41(2), 278-287.

- March, J. G., \& Olsen, J. P. (1989). Rediscovering institutions. The Organizational Basis of Politics. New York: The Free Press.

- Mekonnen, M. M., \& Hoekstra, A. Y. (2016). Four billion people facing severe water scarcity. Science Advances, 2(2), e1500323-e1500323. https://doi.org/10.1126/sciadv.1500323

- Mol, A. P. J. (2006). Environmental governance in the Information Age: the emergence of informational governance. Environment and Planning C: Government and Policy, 24(4), 497-514. https://doi.org/10.1068/c0508j

- Muhren, W. J., \& Van De Walle, B. (2010). A call for sensemaking support systems in crisis management. Studies in Computational Intelligence, 281, 425-452. https://doi. org/10.1007/978-3-642-11688-9_16

- Nyamekye, A. B., Dewulf, A., Van Slobbe, E., Termeer, C. J. A. M., \& Pinto, C. (2018). Governance arrangements and adaptive decision-making in rice farming systems in Northern Ghana. NJAS - Wageningen Journal of Life Sciences, (July), 0-1. https://doi.org/10.1016/j. njas.2018.07.004

- OECD. (2011). Water Governance in OECD Countries. OECD Publishing. https://doi. org/10.1787/9789264119284-en

- Pahl-Wostl, C., Sendzimir, J., Jeffrey, P., Aerts, J., Berkamp, G., \& Cross, K. (2007). Managing Change toward Adaptive Water Management through Social Learning. Ecology And Society, 12(2), article30-article30.

- Peters, B. G., \& Pierre, J. (2016). Comparative Governance. Rediscovering the Functional Dimension of Governing. Cambridge: Cambridge University Press.

- Peters, B. G., \& Zittoun, P. (2016). Contemporary approaches to public policy: Theories, controversies, and perspectives. London: Palgrave Macmillan. https://doi.org/10.1057/978-1137-50494-4

- Pot, W. D., Dewulf, A., Biesbroek, G. R., \& Verweij, S. (2019). What makes decisions about urban water infrastructure forward looking? A fuzzy-set qualitative comparative analysis of investment decisions in 40 Dutch municipalities. Land Use Policy, 82, 781-795. https://doi. org/10.1016/j.landusepol.2018.12.012

- Rhodes, R. (2007). Understanding Governance: Ten Years On. Organization Studies, 28(8), 1243-1264. https://doi.org/10.1177/0170840607076586

- Rist, S., Chiddambaranathan, M., Escobar, C., \& Wiesmann, U. (2006). “It was Hard to Come to Mutual Understanding ..." - The Multidimensionality of Social Learning Processes 
Concerned with Sustainable Natural Resource Use in India, Africa and Latin America. Systemic Practice and Action Research, 19(3), 219-237. https://doi.org/10.1007/s11213-0069014-8

- Rittel, H. W., \& Webber, M. M. (1973). Dilemmas in a General Theory of Planning. Policy Sciences, 4, 155-169.

- Roberts, N. C. (2000). Wicked problems and networks approaches to resolution. International Public Management Review, 1(1), 1-19. https://doi.org/10.1016/S0732-1317(01)11006-7

- Schmidt, V. a. (2008). Discursive Institutionalism: The Explanatory Power of Ideas and Discourse. Annual Review of Political Science, 11(1), 303-326. https://doi.org/10.1146/ annurev.polisci.11.060606.135342

- Scholz, G., Dewulf, A., \& Pahl-Wostl, C. (2014). An Analytical Framework of Social Learning Facilitated by Participatory Methods. Systemic Practice and Action Research, 27(6), 575-591. https://doi.org/10.1007/s11213-013-9310-z

- Simon, H. A. (1955). A Behavioral Model of Rational Choice. The Quarterly Journal of Economics, 69(1), 99-118.

- Stevens, T. M., Aarts, N., Termeer, C. J. A. M., \& Dewulf, A. (2016). Social media as a new playing field for the governance of agro-food sustainability. Current Opinion in Environmental Sustainability, 18, 99-106. https://doi.org/10.1016/j.cosust.2015.11.010

- Stoker, G. (1998). Governance as theory: five propositions. International Social Science Journal, 50(155), 17-28. https://doi.org/10.1111/1468-2451.00106

- Stone, D. A. (2002). Decisions. In Policy Paradox. The art of political decision-making (p. 232-257)). Glenview: Scott.

- Sutcliffe, K. M., \& Weick, K. E. (2007). Managing the Unexpected: Resilience Performance in an Age of Uncertainty (2nd Ed.). San Francisco: Jossey-Bass. https://doi.org/10.1093/ oxfordhb/9780199734610.013.0064

- Termeer, C. J. A. M., Dewulf, A., Breeman, G. E., \& Stiller, S. J. (2015). Governance Capabilities for Dealing Wisely With Wicked Problems. Administration \& Society, 47(6), 680-710. https:// doi.org/10.1177/0095399712469195

- Torfing, J., Peters, B. G., Pierre, J., \& Sorensen, E. (2012). Interactive Governance. Advancing the paradigm. Oxford: Oxford University Press.

- Tuckett, D., Mandel, A., Mangalagiu, D., Abramson, A., Hinkel, J., Katsikopoulos, K., ... Wilkinson, A. (2015). Uncertainty, Decision Science, and Policy Making: A Manifesto for a Research Agenda. Critical Review, 27(2), 213-242. https://doi.org/10.1080/08913811.2015.1037078

- Van Lieshout, M., Dewulf, A., Aarts, N., \& Termeer, C. (2017). The Power to Frame the Scale? Analysing Scalar Politics over, in and of a Deliberative Governance Process. Journal of Environmental Policy \& Planning, 19(5), 550-573. https://doi.org/10.1080/152390 8X.2014.936581

- Vangen, S., Hayes, J. P., \& Cornforth, C. (2015). Governing Cross-Sector, Inter-Organizational Collaborations. Public Management Review, 17(9), 1237-1260. https://doi.org/10.1080/1471903 7.2014 .903658 
- Vink, M. J., Boezeman, D., Dewulf, A., \& Termeer, C. J. A. M. (2013). Changing climate, changing frames: Dutch water policy frame developments in the context of a rise and fall of attention to climate change. Environmental Science and Policy, 30, 90-101. https://doi. org/10.1016/j.envsci.2012.10.010

- Vörösmarty, C. J., Hoekstra, A. Y., Bunn, S. E., Conway, D., \& Gupta, J. (2015). Fresh water goes global. Science, 349(6247), 478-478. https://doi.org/10.1126/science.349.6247.478-a

- Weick, K. E. (1979). The social psychology of organizing. Reading: Addison-Wesley.

- Weick, K. E. (1995). Sensemaking in organizations. Thousand Oaks: Sage.

- Weick, K. E., Sutcliffe, K. M., \& Obstfeld, D. (2005). Organizing and the Process of Sensemaking. Organization Science, 16(4), 409-421. https://doi.org/10.1287/orsc.1050.0133

- Woodhouse, P., \& Muller, M. (2017). Water Governance-An Historical Perspective on Current Debates. World Development, 92, 225-241. https://doi.org/10.1016/j. worlddev.2016.11.014

- Xiang, W.-N. (2013). Working with wicked problems in socio-ecological systems: Awareness, acceptance, and adaptation. Landscape and Urban Planning, 110, 1-4. https://doi. org/10.1016/j.landurbplan.2012.11.006

- Yanow, D. (1993). The communication of policy meanings: Implementation as interpretation and text. Policy Sciences, 26(1), 41-61. https://doi.org/10.1007/BF01006496

- Zahariadis, N. (2003). Ambiguity and choice in public policy. Washington, DC: Georgetown University Press. 



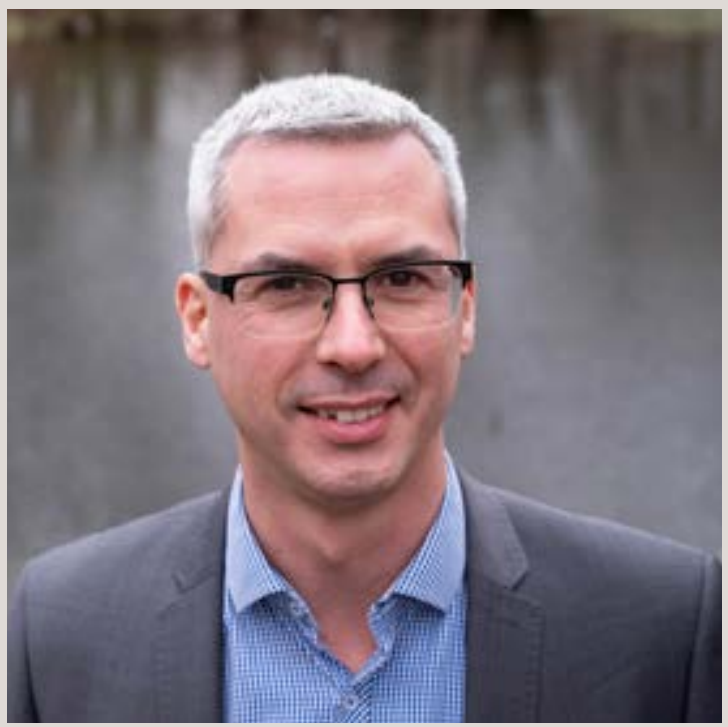

Prof. dr Art R.P.J. Dewulf

'Decisions about water management in river deltas or mountain areas are often based on technical considerations, such as water levels and budgets. But in the era of climate change, decisionmaking on water management is becoming increasingly complex. Whether it's about 'super dikes' in the Netherlands or the water supply for a megacity like Lima, an accurate cost-benefit analysis is not enough. Taking meaningful decisions requires making concrete choices that provide a meaningful perspective on the water system at hand.' 